Journal of Clinical Investigation

Vol. 41, No. 11, 1962

\title{
THYROXINE TURNOVER IN EUTHYROID MAN WITH SPECIAL REFERENCE TO CHANGES WITH AGE
}

\author{
By ROBERT I. GREGERMAN, GEORGE W. GAFFNEY,* AND NATHAN W. SHOCK \\ WITH THE ASSISTANCE OF SAMUEL E. CROWDER
}

(From the Gerontology Branch, National Heart Institute, Bethesda, and the Baltimore City Hospitals, Baltimore, $M d$.)

(Submitted for publication June 7, 1962; accepted July 26, 1962)

For many years the thyroid was thought to be involved in the decrease of basal metabolic rate that accompanies advancing age. Although recent evidence suggests that the change in oxygen consumption may merely reflect a decrease in "metabolic mass" (1), the advent of radioisotope techniques and methods for measuring the level of thyroid hormone in blood led to the hope that new information bearing on the role of the thyroid might become available. We have reviewed the investigations of others and presented our own results in previous publications dealing with the relationship of age to serum protein-bound iodine (PBI) and the thyroidal accumulation of radioiodide in euthyroid man $(2,3)$. The data suggest that the PBI does not change, but that radioiodide accumulation and thyroidal plasma radioiodide clearance decrease with age.

Unfortunately, the radioiodide data are difficult to interpret, since it is not possible to equate a decrease in the uptake of tracer radioiodide with a decrease in thyroid hormone formation (3). Moreover, although the statistical significance of the age-dependent decrease in uptake is clear, the scatter of the individual values is such that the magnitude of the change can be only approximated. Although clinically useful for studying the extremes of thyroid function, there is little evidence that the basal metabolic rate, the serum $\mathrm{PBI}$, or the thyroidal uptake of radioiodide is closely related to the rate of thyroid hormone production in euthyroid man. None of the available studies, therefore, particularly clarifies the issue of whether thyroid activity changes with age.

About ten years ago Riggs reviewed the methods available for estimating quantitatively the rate of thyroid hormone formation, but these have not been used in studies of the relationship of age to

* Present address: Division of Radiological Health, U. S. Public Health Service, Washington 25, D. C. thyroid function (4). A few years later several investigators described the radiothyroxine turnover technique that permits quantitative estimation of thyroid hormone output in man $(5,6,7)$. An important advantage of this method is that it also allows independent determinations of the thyroxine distribution space, pool size, and fractional turnover rate. We undertook the present study hoping to define the range of thyroid function in euthyroid man and the relationship of age both to over-all gland activity and these parameters of thyroid hormone utilization. A preliminary report of our results has been presented (8).

\section{METHODS}

In general the methods used here have been described by Ingbar and Freinkel (6) and by Sterling and Chodos (7). Radioactive thyroxine labeled with $\mathrm{I}^{131}$ was obtained from the Abbott Co. as a 50 per cent propylene glycol solution containing approximately $500 \mu \mathrm{c}$ per $\mathrm{ml}$, with specific activity ranging from 20 to $40 \mathrm{mc}$ per $\mathrm{mg}$. Over the period of this study (from early 1957 to the middle of 1958) many thyroxine preparations were used. The thyroxine was administered within a few days to a week after receipt, although a few determinations were made with material as old as three weeks. Although the labeled material is marketed as "chromatographically pure," our own chromatography in several solvent systems showed other minor components, about half of which were iodide. Each lot was not chromatographed, but a less precise estimate of maximum thyroxine content was routinely made by determining the degree of protein precipitability of the radioactivity. (Thyroxine added to serum can be quantitatively precipitated with the proteins by trichloroacetic acid.) We assumed that none of the contaminants, e.g., iodide, was capable of precipitation, and the thyroxine content of the commercial solution was assayed at 90 per cent or better at the time of receipt. On storage in the refrigerator, the protein precipitability slowly decreased to between 85 to 80 per cent over a two- to three-week period. Standards were based on the amount of protein-precipitable radioactive material at the time of use rather than the total radioactivity of the thyroxine solution. Other workers allude only briefly to the purity of the commercial ma- 
terial. If no corrections for purity have been made in previous reports, the distribution space measurements may be overestimated, since the nonthyroxine components would probably be eliminated from the body much more rapidly than the thyroxine. On the other hand, the magnitude of this correction ordinarily would not exceed 10 per cent.

For intravenous injection, dilution of the thyroxine was made in sterile, pyrogen-free, 50 per cent propylene glycol. Use of this solvent prevented loss of thyroxine to the surfaces of the calibrated syringes used for the injections. Each subject received from 20 to $50 \mu \mathrm{c}$ in a volume of $1 \mathrm{ml}$. To avoid adsorption to glass during the preparation of standards, siliconized flasks were used with a diluting solution of phosphate buffer at $\mathrm{pH} 8$. Protein-containing medium can be used for the same effect. Failure to observe such precautions for avoiding adsorption losses is attended by erratic analytical results.

After injection of the radioactive thyroxine, three days were allowed for in vivo mixing of hormone. In most individuals equilibration appears complete in as little as 24 to 48 hours; a significant number of subjects, however, did not appear to be in equilibrium until the third day. Accordingly, only plasma samples obtained on or after the third day after injection were used in the turnover calculations. Usually five or more plasma samples were obtained from each subject, generally on days $3,5,7,10$, and 12 . Occasionally, only four specimens were available (Table I). Plasma was counted directly, since significant quantities of nonprecipitable radioactivity are not present under these conditions $(6,9)$.

During each turnover study three randomly selected plasma samples from each subject were separately analyzed for protein-bound iodine by using the method of O'Neal and Simms as modified and described elsewhere (2). The mean of the three values was used in the turnover calculations. Plasma radioactivity was measured in a well type scintillation detector. Counting times were set to give a statistical counting error of less than one per cent. Duplicate counts were ordinarily made and the mean value used. Each plasma specimen was counted with its standard to eliminate separate correction for physical decay of radioactivity.

The thyroxine distribution space (TDS), expressed in liters, was calculated from the disappearance curve extrapolated time zero concentration of injected thyroxine (per cent of administered dose per liter of plasma), i.e., 100 divided by the per cent dose per liter at time zero. Although Ingbar and Freinkel have presented objections to the use of extrapolation techniques for the estimation of the TDS (6), our results and those of Sterling and Chodos (7) are based on this method. Any inaccuracy of measurement that may be introduced by extrapolation is probably systematic. We would not expect a systematic error to affect the conclusions derived from the age-dependent changes we have observed.

The half-time of turnover $\left(t_{1}\right)$ is the time in days necessary for the plasma radioactivity to decline to onehalf of the extrapolated time zero concentration. The fractional turnover rate is the fraction (or per cent) of the hormone pool (or TDS) removed per day and is derived from the expression $\ln 2 / \mathrm{t}_{\frac{1}{2}}$ or $.693 / \mathrm{t}_{\frac{1}{2}}$. Calculation of the half-time of turnover and the extrapolated time zero concentration was made by a statistical least squares method. As can be seen from the data presented below (correlation coefficient of the turnover curve, Table I), most curves closely approximate the exponential function.

The exchangeable thyroxine or extrathyroidal thyroxine pool (ETT) may be calculated as the product of TDS (liters) and plasma protein-bound iodine concentration (micrograms per liter). Daily thyroxine degradation rate (TD) (total hormone turnover) is calculated as the product of distribution space, fractional turnover rate, and protein-bound iodine. It should be noted that the results for thyroxine degradation rate are expressed as micrograms of thyroxine iodine per day. Since iodine comprises 65 per cent of the weight of thyroxine, the turnover figures can be multipled by 1.54 to give their equivalents in thyroxine.

The statistical methods used are described by Snedecor (10). When two turnover studies were available for a single subject, the data of the first study were arbitrarily chosen for calculation of the age regressions.

Subjects. The seventy-three individuals who served as subjects were taken from two populations. The younger group (18 to 27 years), twelve healthy young men, had volunteered their services as normal controls to the investigators of the Clinical Center of the National Institutes of Health. The older group included several investigators, but was in the main selected from the population of the Gerontology Branch research ward. A few were from other divisions of the Baltimore City Hospitals. A brief description of the status of these men has been presented elsewhere (3). For purposes of presenting the data, the subjects were grouped as follows: group 1 , decades 2 and 3, ages 18-27; group 2, decade 6, ages 5059 , plus one subject age 48; groups 3 and 4 , decades 7 and 8 , ages $60-69$ and 70-79, respectively ; group 5, decade 9 , ages $80-89$; group 6 , two subjects, ages 90 and 91 .

\section{RESULTS}

Reliability of measurement. In thirty-three individuals turnover studies were performed twice (Tables I and II). The interval between determinations was usually about two months, but varied from one to six months. Correlation coefficients and standard errors of estimate for the various parameters are presented in Table II. Since the duplicate determinations always employed different lots of labeled thyroxine, the excellent reproducibility of the space measurement $(r=0.91)$ would tend to support the reliability of the analytical techniques.

Although there appear to be appreciable differences in some of the pairs of turnover rates in 
THYROXINE TURNOVER AND AGE IN EUTHYROID MAN

TABLE I

Turnover data of individual subjects *

\begin{tabular}{|c|c|c|c|c|c|c|c|c|c|}
\hline Subject & Age & Weight & TDS & $t_{\frac{1}{3}}$ & $\mathbf{k}$ & $\begin{array}{l}\text { Mean } \\
\text { PBI }\end{array}$ & $\begin{array}{l}\text { No. of } \\
\text { plasma } \\
\text { samples }\end{array}$ & $\mathbf{r}$ & $\begin{array}{c}\text { Thyroxine } \\
\text { degradation }\end{array}$ \\
\hline no. & $y r s$ & $\mathrm{~kg}$ & $L$ & days & & $\mu g \%$ & & & $\begin{array}{c}\text { ug thyroxine } \\
\text { I/day }\end{array}$ \\
\hline 1 & 19 & 74.1 & 12.4 & 7.4 & .094 & 5.9 & 11 & -.953 & 69.0 \\
\hline 2 & 20 & 73.2 & 9.0 & 5.3 & .131 & 6.4 & 6 & -.977 & 74.6 \\
\hline 3 & 23 & 71.5 & 9.0 & 6.4 & .108 & 8.9 & 5 & -.954 & 86.6 \\
\hline 4 & 18 & 64.9 & 11.4 & 6.6 & .105 & 6.0 & 10 & -.989 & 71.5 \\
\hline 5 & 26 & 81.6 & 17.3 & 7.2 & .097 & 9.1 & 5 & -.973 & 151.2 \\
\hline 6 & 19 & 74.5 & 11.1 & 6.3 & .110 & 6.6 & 11 & -.936 & 81.6 \\
\hline 7 & 19 & 60.2 & 9.5 & 7.0 & .099 & 7.3 & 11 & $\begin{array}{l}-.930 \\
-.949\end{array}$ & $\begin{array}{l}01.0 \\
68.8\end{array}$ \\
\hline 8 & 22 & 73.8 & 12.1 & 6.6 & .105 & 6.7 & 7 & -.958 & 85.2 \\
\hline 9 & 27 & 58.2 & 18.8 & 7.4 & .094 & 7.1 & 6 & -.975 & 125.1 \\
\hline 10 & 19 & 60.0 & 9.8 & 5.4 & .129 & 6.0 & 11 & -.936 & 75.2 \\
\hline 11 & 21 & 63.1 & 10.6 & 5.6 & .123 & 7.1 & 7 & -.949 & 92.3 \\
\hline 12 & 20 & 79.0 & 17.1 & 8.2 & .085 & 5.7 & 7 & -.970 & 82.7 \\
\hline 13 & 57 & 82.6 & 13.6 & 8.4 & .083 & 5.9 & 5 & -.982 & 65.8 \\
\hline 14 & 48 & 69.9 & 19.2 & 8.1 & .086 & 5.2 & 5 & -.988 & 86.4 \\
\hline 15 & 56 & 50.3 & 10.3 & 6.7 & .103 & 4.5 & 5 & -.982 & 47.8 \\
\hline 16 & 58 & 52.3 & 9.0 & 6.2 & .112 & 6.2 & 6 & -.974 & 62.9 \\
\hline 17 & 55 & 64.7 & 14.8 & 10.3 & .067 & 4.4 & 5 & -.990 & 43.6 \\
\hline 18 & 57 & 48.9 & 7.2 & 7.6 & .091 & 6.4 & 5 & -.977 & 41.9 \\
\hline 19 & 50 & 69.6 & 13.4 & 8.7 & .080 & 6.7 & 8 & -.947 & 71.8 \\
\hline 20 & 50 & 64.0 & 10.2 & 8.6 & .081 & 7.5 & 5 & -.994 & 62.2 \\
\hline 21 & 52 & 58.5 & 10.5 & 7.1 & .098 & 5.4 & 5 & -.989 & 55.7 \\
\hline 22 & 50 & 69.8 & 10.3 & 6.0 & .115 & 5.8 & 5 & -.970 & 68.5 \\
\hline \multirow[t]{2}{*}{23} & 59 & 71.0 & 12.3 & 6.8 & .102 & 6.1 & 4 & -.987 & 75.8 \\
\hline & & $\begin{array}{l}74.4 \\
61.8\end{array}$ & 11.9 & 6.4 & .108 & 5.5 & 5 & -.992 & 69.9 \\
\hline \multirow[t]{2}{*}{24} & 52 & $\begin{array}{l}61.8 \\
60.9\end{array}$ & 15.4 & 8.3 & .084 & 6.1 & 6 & -.997 & 78.0 \\
\hline & & 60.9 & 13.7 & 6.7 & .104 & 4.3 & 5 & -.987 & 60.6 \\
\hline \multirow[t]{2}{*}{25} & 51 & 56.9 & 12.7 & 7.7 & .090 & 5.5 & 5 & -.998 & 62.3 \\
\hline & & 56.0 & 12.1 & 7.0 & .099 & 6.0 & 5 & -.981 & 71.4 \\
\hline \multirow[t]{2}{*}{26} & 57 & 56.2 & 8.9 & 10.3 & .068 & 8.1 & 6 & -.985 & 48.8 \\
\hline & & 56.2 & 10.1 & 10.4 & .067 & 8.3 & 5 & -.989 & 55.6 \\
\hline \multirow[t]{2}{*}{27} & 52 & 71.8 & 13.8 & 7.5 & .093 & 6.8 & 5 & -.991 & 87.8 \\
\hline & & 82.1 & 15.6 & 7.7 & .090 & 4.3 & 5 & -.979 & 60.7 \\
\hline \multirow[t]{2}{*}{28} & 52 & 61.4 & 16.4 & 8.1 & .086 & 5.5 & 5 & -.984 & 77.3 \\
\hline & & 61.4 & 16.4 & 7.5 & .092 & 6.3 & 5 & -.993 & 95.6 \\
\hline \multirow[t]{2}{*}{29} & 57 & 55.3 & 9.9 & 9.4 & .074 & 7.0 & 5 & -.980 & 51.5 \\
\hline & & 56.0 & 9.0 & 7.8 & .089 & 5.2 & 5 & -.995 & 41.5 \\
\hline \multirow[t]{2}{*}{30} & 54 & 65.3 & 8.4 & 7.3 & .095 & 5.9 & 5 & -.988 & 47.6 \\
\hline & & 65.2 & 8.9 & 7.4 & .093 & 7.0 & 4 & -.993 & 58.0 \\
\hline \multirow{2}{*}{$\begin{array}{l}31 \\
32\end{array}$} & 69 & 71.8 & 17.3 & 7.6 & .091 & & 5 & -.997 & \\
\hline & 68 & 50.8 & 10.7 & 8.0 & .087 & 6.8 & 4 & -.995 & 62.8 \\
\hline \multirow{3}{*}{$\begin{array}{l}33 \\
34\end{array}$} & 69 & 69.0 & 12.6 & 10.4 & .067 & 6.1 & 4 & -.991 & 51.3 \\
\hline & 64 & - & 9.7 & 9.2 & .075 & 5.5 & 6 & -.987 & 40.0 \\
\hline & & 71.4 & 9.1 & 7.7 & .090 & 6.0 & 5 & -.985 & 49.3 \\
\hline \multirow[t]{2}{*}{35} & 66 & 69.2 & 12.4 & 7.9 & .087 & 7.7 & 6 & -.984 & 83.1 \\
\hline & & 70.0 & 10.6 & 8.2 & .085 & 7.2 & 5 & -.992 & 64.3 \\
\hline \multirow[t]{2}{*}{36} & 67 & 80.6 & 13.7 & 11.3 & .062 & 6.4 & 5 & -.985 & 54.4 \\
\hline & & 79.1 & 13.6 & 9.0 & .077 & 6.2 & 5 & -.994 & 64.5 \\
\hline \multirow[t]{2}{*}{37} & 64 & 53.5 & 9.6 & 10.0 & .069 & 8.4 & 5 & -.979 & 55.8 \\
\hline & & 52.0 & 8.6 & 9.4 & .074 & 6.9 & 5 & -.990 & 44.1 \\
\hline \multirow[t]{2}{*}{38} & 60 & 51.3 & 8.1 & 7.9 & .088 & 7.6 & 5 & -.966 & 53.9 \\
\hline & & 53.0 & 9.1 & 9.4 & .074 & 7.0 & 5 & -.974 & 47.0 \\
\hline 39 & 64 & 61.2 & 13.1 & 8.9 & .078 & 8.2 & 12 & -.984 & 83.1 \\
\hline & & 65.0 & 11.5 & 10.1 & .069 & 6.4 & 5 & -.994 & 50.5 \\
\hline 40 & 62 & 78.9 & 11.7 & 7.0 & .099 & 7.3 & 5 & -.987 & 84.3 \\
\hline & & 77.9 & 12.0 & 8.2 & .084 & 7.5 & 4 & -.991 & 75.9 \\
\hline 41 & 64 & 69.9 & 9.4 & 10.6 & .065 & 6.6 & 6 & -.979 & 40.4 \\
\hline & & 59.1 & 9.9 & 10.8 & .064 & 7.1 & 6 & -.968 & 45.0 \\
\hline 42 & 63 & 56.9 & 12.5 & 9.1 & .076 & 6.7 & 5 & -.989 & 63.5 \\
\hline & & 66.2 & 11.9 & 9.4 & .074 & 7.2 & 5 & -.989 & 63.4 \\
\hline
\end{tabular}

* Abbreviations: TDS $=$ thyroxine distribution space in liters; $t_{k}=$ half-time of thyroxine turnover in days; $k=$ fractional turnover rate, fraction per day; mean PBI = mean value for protein-bound iodine of three PBI determinations in each turnover study; $r=$ correlation coefficient of the least squares regression calculation of plasma radioactivity on time from which are derived the TDS and $k$. Where replicate turnover studies were performed in the same individual, two values are given. 
TABLE I-(Continued)

\begin{tabular}{|c|c|c|c|c|c|c|c|c|c|}
\hline Subject & Age & Weight & TDS & $t_{\frac{1}{2}}$ & k & $\underset{\text { PBI }}{\text { Mean }}$ & $\begin{array}{c}\text { No. of } \\
\text { plasma } \\
\text { samples }\end{array}$ & $\mathbf{r}$ & $\begin{array}{c}\text { Thyroxine } \\
\text { degradation }\end{array}$ \\
\hline no. & $y r s$ & $\mathrm{~kg}$ & $L$ & days & & $\mu g \%$ & & & $\begin{array}{c}\mu g \text { thyroxine } \\
\text { I/day }\end{array}$ \\
\hline \multirow[t]{2}{*}{43} & 66 & 58.4 & 10.6 & 10.5 & .066 & 4.8 & 6 & -.979 & 33.5 \\
\hline & & 57.5 & 10.7 & 9.5 & .073 & 5.9 & 5 & -.981 & 45.9 \\
\hline 44 & 71 & 59.3 & 10.3 & 8.2 & .085 & 6.9 & 5 & -.994 & 60.0 \\
\hline 45 & 70 & 69.0 & 13.0 & 10.0 & .070 & 5.7 & 6 & -.962 & 51.8 \\
\hline 46 & 79 & 56.5 & 9.1 & 9.5 & .073 & 7.4 & 5 & -.976 & 49.3 \\
\hline 47 & 77 & 50.9 & 9.8 & 9.1 & .076 & 6.7 & 5 & -.990 & 50.3 \\
\hline 48 & 77 & 67.0 & 9.8 & 8.6 & .081 & 6.8 & 5 & -.989 & 53.3 \\
\hline 49 & 78 & 45.3 & 8.1 & 8.5 & .082 & 7.1 & 5 & -.996 & 46.4 \\
\hline 50 & 72 & 79.7 & 14.3 & 9.3 & .075 & 6.2 & 5 & -.993 & 65.6 \\
\hline 51 & 75 & 48.5 & 9.6 & 9.1 & .076 & 5.5 & 5 & -.989 & 39.8 \\
\hline \multirow[t]{2}{*}{52} & 72 & 61.2 & 10.8 & 8.4 & .082 & 7.3 & 5 & -.983 & 65.3 \\
\hline & & 61.6 & 9.1 & 7.9 & .088 & 6.9 & 5 & -.985 & 55.5 \\
\hline \multirow[t]{2}{*}{53} & 79 & 55.6 & 11.1 & 10.7 & .065 & 5.7 & 5 & -.954 & 41.0 \\
\hline & & 60.0 & 10.9 & 11.7 & .059 & 7.4 & 5 & -.959 & 47.5 \\
\hline \multirow[t]{2}{*}{54} & 76 & 58.7 & 10.5 & 8.2 & .085 & 6.8 & 6 & -.972 & 60.5 \\
\hline & & 59.0 & 9.6 & 9.2 & .075 & 6.5 & 5 & -.977 & 47.0 \\
\hline \multirow[t]{2}{*}{55} & 75 & 52.9 & 12.9 & 8.4 & .082 & 6.1 & 5 & -.991 & 65.1 \\
\hline & & 54.8 & 13.3 & 7.7 & .090 & 6.0 & 5 & -.995 & 71.8 \\
\hline \multirow[t]{2}{*}{56} & 70 & 69.4 & 10.7 & 8.3 & .084 & 7.0 & 5 & -.982 & 62.3 \\
\hline & & 74.4 & 10.7 & 8.9 & .078 & 6.1 & 5 & -.989 & 50.8 \\
\hline \multirow[t]{2}{*}{57} & 71 & 53.1 & 11.5 & 9.2 & .075 & 6.3 & 5 & -.963 & 54.3 \\
\hline & & 53.1 & 9.9 & 7.2 & .096 & 6.5 & 6 & -.971 & 61.9 \\
\hline \multirow[t]{2}{*}{58} & 74 & 45.1 & 10.3 & 12.0 & .058 & 6.6 & 5 & -.985 & 39.6 \\
\hline & & 46.0 & 9.8 & 10.2 & .068 & 6.4 & 5 & -.976 & 42.7 \\
\hline 59 & 82 & 56.1 & 9.9 & 10.0 & .070 & 7.1 & 5 & -.997 & 49.1 \\
\hline 60 & 80 & 57.0 & 8.3 & 8.5 & .082 & 6.8 & 5 & -.986 & 46.0 \\
\hline 61 & 91 & 49.0 & 7.0 & 7.3 & .095 & 6.4 & 5 & -.985 & 42.9 \\
\hline 62 & 82 & 63.9 & 10.1 & 7.1 & .097 & 5.6 & 5 & -.976 & 55.2 \\
\hline 63 & 85 & 52.4 & 9.9 & 9.6 & .072 & 6.0 & 5 & -.995 & 43.3 \\
\hline 64 & 82 & 60.1 & 9.0 & 9.4 & .074 & 6.3 & 6 & -.976 & 42.1 \\
\hline 65 & 84 & 60.8 & 9.6 & 9.4 & .074 & 7.2 & 5 & -.984 & 50.6 \\
\hline \multirow[t]{2}{*}{66} & 80 & 59.8 & 10.8 & 8.7 & .080 & 5.7 & 5 & -.965 & 48.5 \\
\hline & & 60.9 & 10.6 & 7.8 & .089 & 6.0 & 5 & -.986 & 56.6 \\
\hline \multirow[t]{2}{*}{67} & 85 & 59.2 & 10.2 & 8.7 & .080 & 6.1 & 5 & -.986 & 49.0 \\
\hline & & 58.4 & 10.7 & 8.2 & .084 & 5.4 & 5 & -.993 & 48.5 \\
\hline \multirow[t]{2}{*}{68} & 84 & 51.4 & 9.7 & 10.8 & .064 & 6.6 & 6 & -.967 & 40.7 \\
\hline & & 49.9 & 8.6 & 11.6 & .060 & 6.5 & 6 & -.983 & 33.4 \\
\hline \multirow[t]{2}{*}{69} & 83 & 39.4 & 6.9 & 9.7 & .072 & 6.3 & 5 & -.992 & 31.4 \\
\hline & & 49.9 & 6.8 & 9.2 & .075 & 6.2 & 5 & -.980 & 31.5 \\
\hline \multirow[t]{2}{*}{70} & 85 & 54.4 & 9.4 & 8.9 & .078 & 5.0 & 5 & -.990 & 36.8 \\
\hline & & 56.9 & 9.8 & 8.1 & .085 & 6.1 & 5 & -.994 & 50.8 \\
\hline \multirow[t]{2}{*}{71} & 87 & 68.8 & 9.7 & 9.8 & .071 & 6.0 & 5 & -.983 & 41.1 \\
\hline & & 77.8 & 9.3 & 9.2 & .076 & 7.0 & 5 & -.986 & 49.1 \\
\hline \multirow[t]{2}{*}{72} & 90 & 63.5 & 11.1 & 9.1 & .076 & 5.0 & 5 & -.993 & 41.8 \\
\hline & & 63.7 & 10.5 & 8.7 & .079 & 5.8 & 5 & -.997 & 47.9 \\
\hline \multirow[t]{2}{*}{73} & 83 & 53.9 & 7.9 & 9.6 & .072 & 6.4 & 4 & -.969 & 36.7 \\
\hline & & 53.2 & 7.6 & 9.0 & .077 & 5.8 & 5 & -.996 & 33.6 \\
\hline
\end{tabular}

those 33 individuals who had replicate determinations, analysis of covariance fails to reveal statistically significant differences between the slopes of the pairs of plasma disappearance curves. A single exception was Subject 52, in whom the slopes yielded half-times of turnover of 8.3 and 6.7 days. These values are different at the 5 per cent level. Significant changes from time to time in the rate of thyroxine turnover may indeed occur under normal conditions, but these changes cannot easily be shown to be statistically significant with the present technique.
Age regression with group 1 omitted. Because of the absence of subjects between ages 30 and 50 and the possible effect of this on the statistical calculations, Table III includes regression calculations, with the youngest group (ages 18-27) omitted. The significance of the regressions is, however, essentially unchanged.

Protein-bound iodine. Analysis of the data fails to reveal any age-dependent change in protein-bound iodine in this series $(r=-0.16 ; 0.2$ $>p>0.1)$. The mean PBI for the seventy-two subjects was $6.5 \mu \mathrm{g}$ per $100 \mathrm{ml}$. We have already 
TABLE II

Statistical comparison of variability of duplicate turnover studies performed in the same individual (33 subjects)

\begin{tabular}{|c|c|c|c|}
\hline & $\begin{array}{l}\text { Correlation } \\
\text { coefficient, } r \\
\text { (first study } \\
\text { vs. second) }\end{array}$ & $\begin{array}{l}\text { Mean value } \\
\quad \text { for } \\
\text { all ages* }\end{array}$ & $\begin{array}{l}\text { Standard error } \\
\text { of estimate } \\
\sigma \text { est. }\end{array}$ \\
\hline $\begin{array}{l}\text { Thyroxine distribution } \\
\text { space, TDS, L }\end{array}$ & 0.91 & 11.19 & 0.89 \\
\hline $\begin{array}{l}\text { Fractional turnover } \\
\text { rate, } \mathrm{k}\end{array}$ & 0.60 & 0.085 & 0.01 \\
\hline $\begin{array}{l}\text { Half-time of turnover, } \\
t_{3} \text {, days }\end{array}$ & 0.60 & 8.42 & 1.04 \\
\hline $\begin{array}{l}\text { Protein-bound iodine, } \\
\quad \mu g \text { I per cent }\end{array}$ & 0.38 & 6.45 & 0.36 \\
\hline $\begin{array}{l}\text { Thyroxine degradation } \\
\text { rate, TD, } \mu \mathrm{g} \text { thyroxine } \\
\text { I per day }\end{array}$ & 0.70 & 60.63 & 9.59 \\
\hline
\end{tabular}

* 72 subjects.

published elsewhere a detailed discussion of the relationship of age to serum protein-bound iodine (2). It should be emphasized that the PBI method used in the present study gives values about twenty per cent higher than the method used by several other investigators in conjunction with their own turnover studies (see reference 2). In comparing the thyroxine degradation figures of different authors, the analytical technique for protein-bound iodine should be kept in mind.

Thyroxine distribution space. The relationship of age to the thyroxine distribution space is shown in Figure 1, Table III, and Table IV. The means and their standard errors are shown for the group of subjects aged 18 to 27 and by decades for the groups belonging to decades 6 through 9 (Figure 1). Because of the absence of subjects in decades 4 and 5, the precise characteristics of the age regression are not clear. This may be a nonlinear relationship. Even assuming linear regression, however, the statistical significance is unquestionable $(\mathrm{p}<.001$, Table III), although the correlation is not close $(r=-0.34$, all subjects; $r=$ -0.45 , ages $18-27$ omitted). The age regres-

TABLE III

Statistical analysis of regression on age of thyroxine turnover

\begin{tabular}{|c|c|c|c|c|c|}
\hline & $\begin{array}{l}\text { Number of } \\
\text { subjects }\end{array}$ & $\begin{array}{l}\text { Slope of } \\
\text { regression } \\
b\end{array}$ & $\begin{array}{l}\text { Standard error } \\
\text { of estimate } \\
\text { of slope } \\
\text { So }\end{array}$ & $\begin{array}{l}\text { Correlation } \\
\text { coefficient } \\
r\end{array}$ & $\begin{array}{l}\text { Level of statistical } \\
\text { significance }\end{array}$ \\
\hline $\begin{array}{l}\text { Thyroxine distribution } \\
\text { space, TDS, L }\end{array}$ & $\begin{array}{l}73 \\
61^{*}\end{array}$ & $\begin{array}{c}U / y r \times 10^{3} \\
-43.7 \\
-90.2\end{array}$ & $\begin{array}{c}U / y r \times 10^{3} \\
14.2\end{array}$ & $\begin{array}{l}-0.34 \\
-0.45\end{array}$ & $\begin{array}{l}\mathrm{p}<.001 \\
\mathrm{p}<.001\end{array}$ \\
\hline $\begin{array}{l}\text { Fractional turnover } \\
\text { rate, } \mathrm{k}\end{array}$ & 73 & -0.503 & -0.066 & -0.67 & $\mathrm{p}<.001$ \\
\hline $\begin{array}{l}\text { Half-time of turnover, } \\
t_{b} \text {, days }\end{array}$ & $\begin{array}{l}73 \\
61^{*}\end{array}$ & $\begin{array}{l}43.4 \\
37.8\end{array}$ & 6.3 & $\begin{array}{l}+0.67 \\
+0.37\end{array}$ & $\begin{array}{l}\mathrm{p}<.001 \\
\mathrm{p}<.005\end{array}$ \\
\hline $\begin{array}{l}\text { Protein-bound iodine, } \\
\text { g I per cent }\end{array}$ & 72 & -6.8 & & -0.16 & $0.2>p>0.1$ \\
\hline $\begin{array}{c}\text { Exchangeable thyroxine } \\
\text { ETT, } \mu \mathrm{g} \text { thyroxine I }\end{array}$ & 72 & $-3.71 \dagger$ & $0.98 t$ & -0.41 & $\mathrm{p}<.001$ \\
\hline $\begin{array}{l}\text { Thyroxine degradation } \\
\text { rate, TD, } \mu \text { g thy- } \\
\text { roxine I per day }\end{array}$ & $\begin{array}{l}72 \\
60^{*}\end{array}$ & $\begin{array}{l}-669 \\
-661\end{array}$ & 84.6 & $\begin{array}{l}-0.69 \\
-0.57\end{array}$ & $\begin{array}{l}\mathrm{p}<.001 \\
\mathrm{p}<.001\end{array}$ \\
\hline
\end{tabular}

* Ages 18-27 omitted.

$\dagger$ Not multiplied by $10^{3}$. 


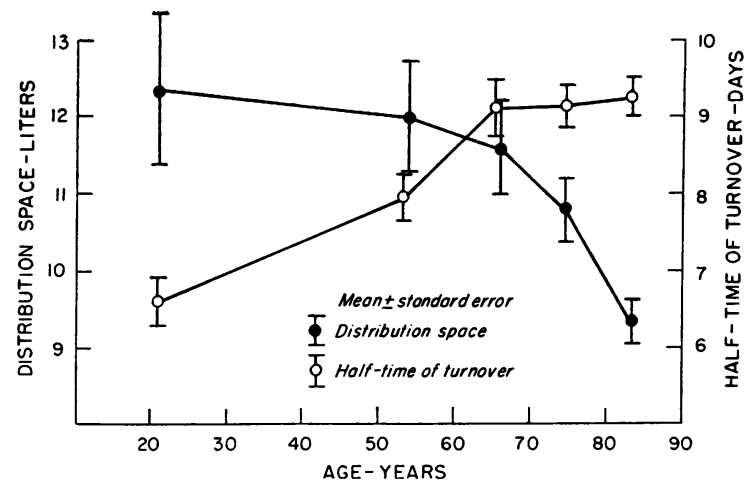

Fig. 1. Relationship of age to thyroxine DistriBUTION SPACE AND HALF-TIME OF TURNOVER, BY AGE Groups. Total number of subjects, 73. The lines connecting means are drawn by inspection. The vertical lines represent one standard error above and below the mean for each group.

sion is calculated, here and subsequently, on the basis of the individual values and not on the basis of the mean values by decades.

Half-time of turnover. Figure 1 and Table IV show the values for half-time of turnover of thyroxine relative to age. The mean value for the group aged 18 to 27 is 6.7 days. Strict compari- son can be made only with the group of young normal subjects of comparable age studied by Sterling and Chodos (7), who report an identical value. Increase in half-time of turnover is seen in the older subjects, although mean values do not significantly increase beyond decade 7 . A nonlinear relationship to age is suggested, but even assuming linearity, the age change is highly significant statistically $(\mathrm{r}=+0.63, \mathrm{p}<.001$, all subjects; $r=+0.37, p<.005$, ages $18-27$ omitted; Table III). The half-time of turnover increases from a mean of 6.7 days in decade 3 to 9.1 days in decade 7.

Exchangeable thyroxine. The calculated exchangeable thyroxine or extrathyroidal thyroxine pool decreases with age $(r=-0.41$, Tables III and IV), and the change is statistically significant $(p<.001)$. The regression largely reflects the decrease with age in the thyroxine distribution space.

Daily thyroxine degradation rate. The most striking age-dependent change is evident in the thyroxine degradation rate. The regression appears to be approximately linear (Figure 2), is highly significant statistically $(\mathrm{p}<.001$, Table

TABLE IV

Summary of mean values by age groups *

\begin{tabular}{|c|c|c|c|c|c|c|c|c|}
\hline Group & $\begin{array}{c}\text { Mean } \\
\text { age }\end{array}$ & Subjects & TDS & $t_{\frac{1}{3}}$ & & PBI & $\begin{array}{c}\text { Exchangeable } \\
\text { thyroxine }\end{array}$ & $\begin{array}{c}\text { Thyroxine } \\
\text { degradation } \\
\text { rate }\end{array}$ \\
\hline no. & $y r s$ & no. & $L$ & days & $k$ & $\mu g \%$ & $\mu g$ thyroxine $I$ & $\begin{array}{l}\mu g \text { thyroxine } \\
\text { I/day }\end{array}$ \\
\hline 1 & 21.1 & 12 & $\begin{array}{r}12.34 \\
\pm 3.46\end{array}$ & $\begin{array}{r}6.61 \\
\pm 0.87\end{array}$ & $\begin{array}{r}.107 \\
\pm 0.15\end{array}$ & $\begin{array}{r}6.90 \\
\pm 1.10\end{array}$ & $\begin{array}{r}854.5 \\
\pm 303.3\end{array}$ & $\begin{array}{r}88.65 \\
\pm 24.88\end{array}$ \\
\hline 2 & 53.7 & 18 & $\begin{array}{r}12.01 \\
\pm 3.15\end{array}$ & $\begin{array}{r}7.94 \\
\pm 1.22\end{array}$ & $\begin{array}{r}.089 \\
\pm .014\end{array}$ & $\begin{array}{r}6.06 \\
\pm 1.00\end{array}$ & $\begin{array}{r}716.6 \\
\pm 171.8\end{array}$ & $\begin{array}{r}63.08 \\
\pm 14.45\end{array}$ \\
\hline 3 & 65.1 & 13 & $\begin{array}{r}11.65 \\
\pm 2.39\end{array}$ & $\begin{array}{r}9.10 \\
\pm 1.35\end{array}$ & $\begin{array}{r}.078 \\
\pm .012\end{array}$ & $\begin{array}{r}6.83 \dagger \\
\pm 1.07\end{array}$ & $\begin{aligned} & 764.9 \dagger \\
\pm & 171.3\end{aligned}$ & $\begin{aligned} & 58.84 \dagger \\
\pm & 17.34\end{aligned}$ \\
\hline 4 & 74.4 & 15 & $\begin{array}{r}10.79 \\
\pm 1.61\end{array}$ & $\begin{array}{r}9.17 \\
\pm 1.06\end{array}$ & $\begin{array}{r}.076 \\
\pm .008\end{array}$ & $\begin{array}{r}6.54 \\
\pm 0.60\end{array}$ & $\begin{array}{r}700.9 \\
\pm 88.2\end{array}$ & $\begin{array}{r}53.63 \\
\pm 9.30\end{array}$ \\
\hline 5 & 83.2 & 13 & $\begin{array}{r}9.34 \\
\pm 1.05\end{array}$ & $\begin{array}{r}9.25 \\
\pm 0.89\end{array}$ & $\begin{array}{r}.076 \\
\pm .008\end{array}$ & $\begin{array}{r}6.24 \\
\pm 0.60\end{array}$ & $\begin{array}{r}576.8 \\
\pm \quad 84.4\end{array}$ & $\begin{array}{r}43.89 \\
\pm \quad 6.66\end{array}$ \\
\hline 6 & 90.5 & 2 & $\begin{array}{r}9.05 \\
\pm 2.89\end{array}$ & $\begin{array}{r}8.19 \\
\pm 1.29\end{array}$ & $\begin{array}{r}.086 \\
\pm .013\end{array}$ & $\begin{array}{r}5.70 \\
\pm 1.05\end{array}$ & $\begin{array}{r}530.3 \\
\pm \quad 34.9\end{array}$ & $\begin{array}{r}42.38 \\
\pm 0.77\end{array}$ \\
\hline All ages & 60.8 & 73 & $\begin{array}{r}11.19 \\
\pm 2.67\end{array}$ & $\begin{array}{r}8.42 \\
\pm 1.44\end{array}$ & $\begin{array}{r}.085 \\
\pm .016\end{array}$ & $\begin{array}{c}\quad 6.45 \ddagger \\
\pm 0.93\end{array}$ & $\begin{array}{r}713.9 \ddagger \\
\pm 191.9\end{array}$ & $\begin{array}{r}60.63 \ddagger \\
\pm 20.57\end{array}$ \\
\hline
\end{tabular}

* See text and Table I for explanation of symbols. Calculations based on first turnover study for each subject. Values are means $\pm S D$ for each age group. $S D=$ standard deviation of the distribution.

+ Number of subjects $=12$; mean age 64.8 .

$\ddagger$ Number of subjects $=72$. 


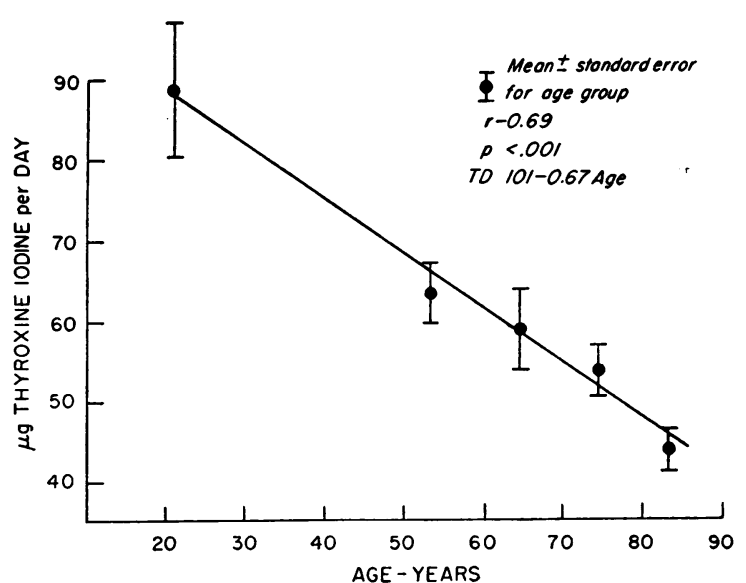

Fig. 2. Relationship of AgE to DaILy thyroxine DEGRADATION, BY AGE GROUPS. The regression line is calculated from the regression analysis based on individual values for 72 subjects. The vertical bars represent one standard error above and below the mean for each group.

III), and has a good correlation with age $(\mathrm{r}=-$ 0.69 , all subjects; $r=-0.57$, ages 18 to 27 omitted; Table III). Over the age span measured, thyroxine degradation declines from a mean of 88.7 to $43.9 \mu \mathrm{g}$ of thyroxine iodine per day in decades 3 and 9 , respectively, a decrease of about 50 per cent.

\section{DISCUSSION}

Since we have recently reviewed the previous efforts of others and ourselves to measure the relationship of age to thyroid function and have commented upon the limitations of older methodology (3), a detailed discussion of these aspects of the problem is not necessary here. In viewing our results with the radiothyroxine turnover technique, one should keep in mind that the measured function, degradation, is equivalent to thyroid hormone synthesis, at least for the steady state in normal man (6).

The calculated reduction with age in thyroxine degradation rate is obviously dependent on changes in either serum hormone level (protein-bound iodine), distribution space, or fractional turnover rate. It is to be noted that the serum hormone level shows no age-dependent change despite an apparent decrease in gland hormone output. The contrast between this observation and the fall in serum hormone level that results from the decrease in thyroid hormone output of primary hypothyroidism and secondary hypothyroidism due to hypopituitarism suggests an interesting homeostatic mechanism.

The observed decrease in throxine degradation rate is in fact the result of decreases in both fractional turnover rate and the thyroxine distribution space. An age-dependent decrease in activity of the enzyme system(s) responsible for thyroxine degradation could explain the slowed removal of hormone. Secondarily, the thyroid would decrease gland output via mediation of the normal blood hormone-pituitary-thyroid "homeostat."

In recent years, numerous observations seem to have established clearly that thyroxine-protein interaction is a major determinant of thyroxine turnover in a variety of circumstances (11-16). Robbins and Rall originally suggested that in euthyroid and hyperthyroid individuals, thyroid hormone action is a function of the concentration of "free" hormone in plasma and that the "free" hormone level may also be an important determinant of the rate of thyroxine metabolism (11). Observations on the relationship of age to thyroxine-protein interactions and the concentration of "free" thyroxine in plamsa, e.g., as recently measured by Sterling and Hegedus (17), would not only be interesting but might provide an opportunity for a definitive assessment of the importance of these factors as determinants of thyroxine turnover in the euthyroid state. The range of normal values for turnover is certainly wider than previously appreciated and should allow an adequate statistical correlation.

The decrease with age in thyroxine distribution space may be related to known changes with age of "metabolic mass." Although the limits of the thyroxine space cannot be precisely defined, and although the hormone is probably unequally distributed within the vascular and extracellular spaces and the tissues of a variety of organs, especially liver and muscle, one might nonetheless expect that a decrease in quantity of metabolically active tissue could be reflected in a concomitant decrease in thyroxine space. Several studies suggest that "metabolic mass" decreases with age. Data from our own laboratory indicate a decrease in body water of about 15 per cent over the 30year age span 50 to 80 years $(1,18)$. Measuring total body potassium ( $\mathrm{K}^{40}$ whole body counting) or exchangeable potassium ( $\mathrm{K}^{42}$ isotope dilution) as an index of metabolic mass, several workers 
have noted an age decrease of between 13 per cent (19) and 20 per cent (20) over the same age span. The present data indicate a decrease in the thyroxine space of similar magnitude, about 20 per cent, and it is tempting to ascribe the change simply to a decrease in the amount of metabolically active tissue. Some support for this line of reasoning comes from the observation that in the rat the thyroxine space seems to be closely related to metabolic mass (actually body weight) over a wide range (21).

The decrease in TDS from middle to old age accounts for a large portion of the calculated decrease in thyroxine degradation rate in this interval. The remainder of the decrease in degradation results from the decreasing fractional turnover rate. Over the entire age span measured, however, there is a decrease in total turnover which is independent of the change in distribution space and is due to a decrease in fractional turnover. Between decades 3 and 6 the fractional turnover rate is significantly decreased $\left(t_{\frac{1}{2}} 6.7\right.$ vs. 7.9 days), while the thyroxine distribution space is unchanged. Between decades 6 and 7 further slowing is evident ( $t_{\frac{1}{2}} 7.9$ vs. 9.1 days), but thereafter no additional change occurs. There is no reason to attribute any of this change in fractional turnover rate to the age-dependent decrease in metabolic mass, per se, since, at least in the rat, fractional turnover, in contrast to the thyroxine space, is independent of body weight (21). Moreover, the mean half-time of thyroxine turnover in children (whose metabolic mass is obviously small) was recently reported as 4.95 days (22). The latter observation indicates that the relationship of age to fractional turnover rate extends over a very wide range indeed.

A progressive decrease in physical activity accompanies senescence, and one might suspect that activity could affect the turnover of thyroid hormone. An unequivocal answer to this question is not presently possible. Short term observations in two subjects suggest that moderate physical activity does not accelerate thyroxine turnover (23), although in animals extreme muscular effort does appear to exert an accelerating effect (24). Recently Reichlin, Koussa, and Witt studied the effect of chlorpromazine-induced sleep therapy in psychotic subjects in a direct attempt to assess the effect of activity on thyroxine turnover (25).
Contrary to expectation, a significant increase in the fractional rate of turnover accompanied the drug-induced inactivity. However, an accelerating effect of chlorpromazine on thyroxine metabolism analogous to that seen with dinitrophenol $(26,27)$ could not be excluded. An additional observation was that thyroxine turnover appeared normal, i.e., was not decreased, in paraplegic individuals inactive for prolonged periods.

Although both estrogens $(28,29)$ and androgens (12) have been shown to affect thyroxine turnover, the importance of these hormones in the metabolism of thyroxine under physiologic circumstances is not clear. The observations that androgens decrease the half-time of turnover and that androgen secretion declines with age lead one to consider, at least, the latter phenomenon as an explanation for our finding that thyroxine half-time of turnover increases with age. In this view, one would picture the shorter half-time of the younger male as an androgen effect which is removed with age as androgen output decreases. Actually there is little to support this idea. Agecontrolled studies that compare thyroxine metabolism in males and females are, unfortunately, not available, but the meager information in the published reports does not suggest that the fractional turnover of thyroxine is ordinarily more rapid in the male than the female. In the rat-where such data are available - the reverse is the case; fractional turnover is more rapid in the female (21). These observations are in contrast to the findings that estrogens in high dosage greatly increase the half-time of thyroxine turnover. A similar estrogen effect presumably is responsible for the elevated serum PBI and TBP that occurs during pregnancy, although thyroxine turnover studies during pregnancy have not been reported. In neither man (30) nor the rat (31) do adrenal hormones appear to affect thyroxine metabolism significantly. Thus, one cannot readily ascribe any of the age-dependent changes in thyroxine turnover to the metabolic effects of other hormones, the levels of which might in turn be agerelated.

Thyroxine fractional turnover rate is increased in hyperthyroidism $(6,7,13,14)$, but it is thought to be decreased in myxedema $(7,13)$. Our present observations may have some bearing upon the latter contention. Since a significant number 
of the studied myxedematous subjects were in an older age group, the decreased turnover may perhaps be attributable, at least in part, to age. A study of thyroxine turnover in myxedematous individuals before and after thyroid replacement therapy, in which treatment resulted in increased fractional turnover in most of the subjects (13), suggests that the hypothyroid state is indeed accompanied by a decrease in thyroxine fractional turnover rate. In view of earlier results (6), however, lack of uniform response to treatment (13), lack of statistical comparison of the paired turnover curves, and the presently demonstrated effect of age on thyroxine turnover, one might yet be cautious in concluding that myxedema results in decreased thyroxine turnover. Future studies in this area will require closer attention to such factors as age and sex than has hitherto been the case.

Comparison of the values for TDS and exchangeable thyroxine with those published is difficult, chiefly because the number of normal euthyroid individuals recorded in the literature is small. The series of Ingbar and Freinkel (6) cannot be compared, since the ages were not recorded and four of the nine subjects were females. Sterling and Chodos gave values for eight young normal males (7). Although our own values are higher, some of the differences in exchangeable thyroxine can be accounted for by the PBI methodology (2), as well as by the fact that our own results are not corrected to standard surface area or body weight, from which we would expect our own figures to be approximately 20 and 10 per cent higher, respectively. It should be noted that in our own series the mean TDS is essentially the same for both 20- and 50-year-old groups. Sampling may account for the apparent difference between our own series and that of Sterling and Chodos. The reproducibility of the TDS determination in our hands should be kept in mind in this connection.

It has often been observed that elderly hypothyroid persons may require smaller doses of desiccated thyroid than do young individuals to achieve and maintain the euthyroid state. The results in the present study are consistent with these clinical observations, although it should be recalled that it is hazardous to equate oral requirement with thyroxine secretion rate (32).
SUMMARY

1. Thyroxine turnover was studied in 73 euthyroid male subjects of ages 18 to 91 .

2. Thyroxine distribution space and fractional turnover rate were determined from the curve of disappearance of plasma radioactivity after intravenous administration of thyroxine labeled with $\mathrm{I}^{131}$.

3. The thyroxine distribution space decreases with age, but apparently only after decade 6 . It is suggested that this finding may be a result of the decrease of metabolic mass with age.

4. The fractional turnover rate of thyroxine decreases with age until decade 7 , but thereafter no further change is evident.

5. Calculated from the distribution space, fractional turnover rate, and plasma hormone concentration (protein-bound iodine), thyroxine degradation decreases by about 50 per cent over the age span measured, roughly 20 to 80 years.

6 . Since for the steady state hormone degradation is equivalent to hormone production, the results are interpreted to indicate a decrease of thyroid function with age in euthyroid man. The decrease in hormone output is viewed as a homeostatic adjustment necessitated by an age-dependent alteration in the peripheral disposal (degradation, or utilization, or both) of the thyroid hormone.

\section{ACKNOWLEDGMENTS}

The authors wish to express their gratitude to the following individuals without whose help this study might not have been possible. Dr. Robert S. Gordon, Jr., of the National Heart Institute and Dr. James F. O'Rourke of the National Institute of Neurological Diseases and Blindness made available young control subjects at the Clinical Center of the National Institutes of Health. Dr. Melvin Davidoff, Mr. Arthur H. Norris, and Mrs. Eleanor Howard gave invaluable help with the statistical analyses. Miss Margaret Sellmayer skillfully performed the analyses of protein-bound iodine. Mr. Jesse Yaffa provided technical assistance during a portion of the study.

\section{REFERENCES}

1. Shock, N. W. Metabolism and age. J. chron. Dis. 1955, 2, 687.

2. Gaffney, G. W., Gregerman, R. I., Yiengst, M. J., and Shock, N. W. Serum protein-bound iodine concentration in blood of euthyroid men aged 18 to 94 years. J. Geront. 1960, 15, 234.

3. Gaffney, G. W., Gregerman, R. I., and Shock, N. W. The relationship of age to the thyroidal accumula- 
tion, renal excretion, and distribution of radioiodide in euthyroid man. J. clin. Endocr. 1962, 22, 784.

4. Riggs, D. S. Quantitative aspects of iodine metabolism in man. Pharmacol. Rev. 1952, 4, 284.

5. Sterling, K., Lashof, J. C., and Man, E. B. Disappearance from serum of $\mathrm{I}^{131}$-labeled $\mathrm{L}$-thyroxine and L-triiodothyronine in euthyroid subjects. J. clin. Invest. 1954, 33, 1031.

6. Ingbar, S. H., and Freinkel, N. Simultaneous estimation of rates of thyroxine degradation and thyroid hormone synthesis. J. clin. Invest. 1955, 34, 808.

7. Sterling, K., and Chodos, R. B. Radiothyroxine turnover studies in myxedema, thyrotoxicosis, and hypermetabolism without endocrine disease. $\mathrm{J}$. clin. Invest. 1956, 35, 806.

8. Gaffney, G. W., Gregerman, R. I., and Shock, N. W. Thyroid function and senescence in man. Fed. Proc. 1959, 18, 49.

9. Friis, T. Thyroxine metabolism in man estimated by means of $\mathrm{I}^{131}$-labelled L-thyroxine. Acta endocr. 1958, 29, 587.

10. Snedecor, G. W. Statistical Methods, 5th ed. Ames, Iowa State College Press, 1956.

11. Robbins, J., and Rall, J. E. The interaction of thyroid hormones and protein in biological fluids. Recent Progr. Hormone Res. 1957, 13, 161.

12. Federman, D. D., Robbins, J., and Rall, J. E. Effects of methyl testosterone on thyroid function, thyroxine metabolism, and thyroxine-binding protein. J. clin. Invest. 1958, 37, 1024.

13. Sterling, K. Radiothyroxine turnover studies in thyroid disease after therapy. J. clin. Invest. 1958, 37,1348

14. Ingbar, S. H., and Freinkel, N. Studies of thyroid function and the peripheral metabolism of $\mathrm{I}^{131}$ labeled thyroxine in patients with treated Graves' disease. J. clin. Invest. 1958, 37, 1603.

15. Beierwaltes, W. H., and Robbins, J. Familial increase in the thyroxine-binding sites in serum alpha globulin. J. clin. Invest. 1959, 38, 1683.

16. Braverman, L. E., and Ingbar, S. H. The metabolism of thyroid hormones as related to protein binding. J. chron. Dis. 1961, 14, 484.

17. Sterling, K., and Hegedus, A. Measurement of free thyroxine concentration in human serum. J. clin. Invest. 1962, 41, 1031.

18. Shock, N. W., Watkin, D. M., Yiengst, M. J., Norris, A. H., Gaffney, G. W., Gregerman, R. I., and Falzone, J. A., Jr. Age differences in the water content of the body and its relationship to basal oxygen consumption in males. In preparation.
19. Allen, T. H., Anderson, E. C., and Langham, W. H. Total body potassium and gross body composition in relation to age. J. Geront. 1960, 15, 348.

20. Sagild, U. Total exchangeable potassium in normal subjects with special reference to changes with age. Scand. J. clin. Lab. Invest. 1956, 8, 44.

21. Gregerman, R. I. Estimation of thyroxine secretion rate in the rat by the radioactive thyroxine turnover technique: influences of age, sex, and exposure to cold. Endocrinology. In press.

22. Haddad, H. M. Rates of $\mathrm{I}^{131}$-labeled thyroxine metabolism in euthyroid children. J. clin. Invest. 1960, 39, 1590.

23. Lashof, J. C., Bondy, P. K., Sterling, K., and Man, E. B. Effect of muscular exercise on circulating thyroid hormone. Proc. Soc. exp. Biol. (N. Y.) 1954, 86, 233.

24. Escobar del Rey, F., and Morreale de Escobar, G. Studies on the peripheral disappearance of thyroid hormone. III. The effect of running for 12 hours on the $\mathrm{I}^{131}$ distribution in thyroidectomized, 1-thyroxine maintained rats after the injection of $\mathrm{I}^{131}$ labeled 1-thyroxine. Acta Endocr. 1956, 23, 400.

25. Reichlin, S., Koussa, M. G., and Witt, F. W. Effect of prolonged sleep therapy and of chlorpromazine on plasma protein-bound iodine concentration and plasma thyroxine turnover. J. clin. Endocr. 1959, 9, 692.

26. Goldberg, R. C., Wolff, J., and Greep, R. O. The mechanism of depression of plasma protein-bound iodine by 2,4 dinitrophenol. Endocrinology 1955, 56,560 .

27. Castor, C. W., and Beierwaltes, W. Effect of 2,4dinitrophenol on thyroid function in man. J. clin. Endocr. 1956, 16, 1026.

28. Engbring, N. H., and Engstrom, W. W. Effects of estrogen and testosterone on circulating thyroid hormone. J. clin. Endocr. 1959, 19, 783.

29. Dowling, J. T., Freinkel, N., and Ingbar, S. H. The effect of estrogens upon the peripheral metabolism of thyroxine. J. clin. Invest. 1960, 39, 1119.

30. Ingbar, S. H., and Freinkel, N. The influence of ACTH, cortisone, and hydrocortisone on the distribution and peripheral metabolism of thyroxine. J. clin. Invest. 1955, 34, 1375.

31. Beck, R. N. The effect of cortisone and corticotropin on the release and peripheral metabolism of thyroid hormone. Endocrinology 1958, 62, 9.

32. Van Middlesworth, L. Thyroxine requirement and the excretion of thyroxine metabolites in Clinical Endocrinology, E. B. Astwood, Ed. New York, Grune and Stratton, 1960, vol 1, pp. 103-111. 